Institute of Ethiopian Studies, Addis Ababa: Notes for Field-workers

The Institute of Ethiopian Studies, Haile Sellassie I University (P.O. Box I 176, Addis Ababa) intends from time to time to issue reports from scholars on local conditions in various parts of the country, with a view to making information available to anthropologists and others about to engage in field-work in Ethiopia. The first in the series, Mr. F: S. Lister's report on 'Travel and Research in Western Ethiopia', includes useful and interesting information on requirements for entry into Ethiopia, travel routes and shipping, transport conditions in the interior of the country, and relations with local officials.

\title{
Urbanization and Socio-Cultural Change in the Ivory Coast
}

Dr. Robert Stevenson, of Columbia University, New York, is engaged in a field study of Urbanization and Socio-Cultural Change in the Ivory Coast, on a grant from the National Institute of Health. Dr. Stevenson is primarily interested in changes among the Lagoon populations and hopes to co-operate with French scholars with similar interests.

\section{St. Thomas University, Houston, Texas: Exhibition of African Art}

From October 1965 to February 1966 the University of St. Thomas, Houston, Texas, has been offering a course on African art and an exhibition of over 180 rare works. Dr. Mino Badner, Assistant Professor of Art, has been lecturing on the major art styles of the Sudan, Liberia, Ghana, Ivory Coast, Nigeria, Cameroons, and the Congo. The exhibits, consisting of masks, festishes, ancestral figures, and articles of everyday use are arranged according to tribe, and include loans from New York's Museum of Primitive Art and the Museum of Natural History as well as from private collections.

\section{Conference in Edinburgh on 'Joint Research Schemes and Recruitment'}

THE Centre of African Studies at Edinburgh University in association with the Ministry of Overseas Development held a conference from ${ }_{13}$ to 17 September 1965 , the subject of which was ' Joint Research Schemes and Recruitment'. It was attended by ninety delegates from fourteen African universities, thirteen British universities and institutions of higher education and several other bodies concerned with the topics for discussion.

Although the conference was called originally to discuss joint research schemes between North British and African institutions and also recruitment in this northern region for African universities, its terms of reference were soon extended to include almost the whole field of relations between British and African institutions of higher education. One point that emerged strongly from the conference, particularly as a result of the contribution of the African delegates, was that these relations are no longer heavily weighted on the side of British initiative but that there is now a two-way traffic of benefit.

The opening address was given by Dr. N. S. Alexander, Vice-Chancellor of Ahmadu Bello University, who spoke on the problems and opportunities as seen from the viewpoint of an African institution. During the following days of the conference the mornings were devoted to plenary sessions on general problems of starting and working a joint research scheme or other forms of joint activity, together with points arising from existing activities; the issues of secondment to African universities; the problems of African research students in Britain and British research students in Africa; and the question of effective communications. During afternoon sessions the conference broke up into small working groups on disciplinary or inter-disciplinary lines, for example, Architecture, Town and Regional 